\title{
The Effect of Profitability Ratios on Financial Distress in Islamic Commercial Banks in Indonesia
}

\author{
Yennita Sari ${ }^{1}$, Nofinawati ${ }^{2}$, Sarmiana Batubara ${ }^{3}$, Ferri Alfadri ${ }^{4}$ \\ ${ }^{1}$ IAIN Padangsidimpuan (Perbankan Syariah, FEBI, IAIN Padangsidimpuan) \\ ${ }^{2}$ IAIN Padangsidimpuan (Perbankan Syariah, FEBI, IAIN Padangsidimpuan) \\ ${ }^{3}$ IAIN Padangsidimpuan (Perbankan Syariah, FEBI, IAIN Padangsidimpuan) \\ ${ }^{4}$ IAIN Padangsidimpuan (Ekonomi Syariah, FEBI, IAIN Padangsidimpuan) \\ yennitasari@gmail.com ${ }^{1}$, nofinawati@iain-padangsidimpuan.ac.id ${ }^{2}$, sarmianabatubara@iain- \\ padangsidimpuan.ac.id ${ }^{3}$, ferrialfadri@iain-padangsidimpuan.ac.id ${ }^{4}$
}

\begin{abstract}
ABSTRAK
ROA dan ROE berpengaruh terhadap Financial Distress yaitu jika persentase nilai ROA dan ROE berada pada nilai tinggi maka dapat dikatakan bahwa perusahaan masih jauh dari kondisi financial distress. Semakin tinggi hasil pengembalian atas asset berarti semakin tinggi pula jumlah laba bersih yang dihasilkan dan sebaliknya. ROA dan ROEyang mengalami peningkatan dan financial distress mengalami peningkatan terjadi pada bank Muamalat Indonesia pada tahun 2016, Bank Rakyat Indonesia tahun 2016, Bank Negara Indonesia tahun 2016 dan 2018, Bank Central Asia tahun 2017, Bank Syariah Mandiri tahun 2016, Bank Panin Syariah tahun 2017, Bank Mega Syariah tahun 2015, Bank Bukopin Syariah tahun 2016, Bank Victoria Syariah tahun 2018, Maybank Syariah tahun 2017, Bank Tabungan Pensiunan Negara Syariah tahun 2015 dan 2018 dan nilai Return On Asset yang mengalami penurunan dan nilai financial distress juga menurun terjadi pada Bank Mega Syariah tahun 2018, Bank Victoria Syariah tahun 2018, Bank Panin Syariah tahun 2015, dan pada Bank Bukopin Syariah tahun 2018. Rumusan masalah dalam penelitian ini adalah apakah terdapat pengaruh ROA dan ROE terhadap financial distress pada bank umum syariah di Indonesia tahun 2014-2018. Tujuan penelitian ini adalah untuk mengetahui pengaruh dari ROAdan ROE terhadap financial distress pada bank umum syariah di Indonesia tahun 2014-2018. Pembahasan penelitian ini berkaitan dengan analisis laporan keuangan dan rasio profitabilitas dan financial distressdengan menggunakan metode Zmijewski X-score. Penelitian ini merupakan penelitian kuantitatif dengan analisis regresi data panel. Data yang digunakan adalah data time series tahun 2014-2018 yang dipublikasikan melalui website resmi masing-masing bank umum syariah di Indonesia yang di analisis dengan menggunakan Software Eviews 9. ROA secara parsial memiliki nilai thitung < ttabel $(0,5248822<1,67203)$ maka dapat disimpulkan ROA tidak berpengaruh signifikan terhadap financial distress tahun 2014-2018. ROE secara parsial memiliki nilai thitung $<$ ttabel $(-0,545903<1,67203)$ maka dapat disimpulkan ROE tidak berpengaruh signifikan terhadap financial distress tahun 2014-2018. ROA dan ROE secara simultan memiliki nilai Fhitung $>$ Ftabel $(4,664855>2,77)$ yang berarti bahwa kedua variabel mempengaruhi variabel financial distress tahun 2014-2018. Berdasarkan hasil perolehan R2 sebesar 0,592051, artinya 59 persen financial distress dipengaruhi oleh ROA dan ROE sedangkan 41 persen dipengaruhi oleh variabel lain yang tidak dibahas dalam penelitian ini. Kata Kunci: Return On Asset, Return On Equity, Financial Distress
\end{abstract}

\section{ABSTRACT}


POINT Vol. 1, No. 1, Jul 2020

ROA and ROE affect the Financial Distress that is if the percentage value of ROA and ROE is at a high value, it can be said that the company is still far from financial distress. The higher the return on assets means the higher the amount of net profit generated and vice versa. ROA and ROE which have increased and financial distress have increased occurred in Muamalat Indonesia bank in 2016, Bank Rakyat Indonesia in 2016, Bank Negara Indonesia in 2016 and 2018, Bank Central Asia in 2017, Bank Syariah Mandiri in 2016, Bank Panin Syariah in 2017 , Bank Mega Syariah in 2015, Bank Bukopin Syariah in 2016, Bank Victoria Syariah in 2018, Maybank Syariah in 2017, Bank Syariah State Pensioners in 2015 and 2018 and the value of Return on Assets which declined and the value of financial distress also decreased in banks. Mega Syariah in 2018, Bank Victoria Syariah in 2018, Bank Panin Syariah in 2015, and Bank Bukopin Syariah in 2018. Formulation of the problem in this study is whether there is an influence of ROA and ROE on financial distress in Islamic commercial banks in Indonesia in 2014-2018 . The purpose of this study was to determine the effect of ROA and ROE on financial distress in Islamic commercial banks in Indonesia in 2014-2018. The discussion of this study deals with the analysis of financial statements and profitability ratios and financial distress by using the Zmijewski X-score method. This research is a quantitative study using panel data regression analysis. The data used are time series data for 2014-2018 published through the official website of each Islamic commercial bank in Indonesia, which was analyzed using Software Eviews 9. Partial ROA has a tcount value <ttable $(0.5248822$ $<1.67203$ ) it can be concluded that ROA has no significant effect on financial distress in 20142018. ROE partially has a tcount <ttable $(-0.545903<1.67203)$ so it can be concluded that ROE has no significant effect on financial distress in 2014-2018. ROA and ROE simultaneously have a value of Fcount> Ftable (4.664855> 2.77) which means that both variables affect the financial distress variable in 2014-2018. Based on the results of the acquisition R2 of 0.592051 , it means that 59 percent of financial distress is influenced by ROA and ROE while 41 percent is influenced by other variables not discussed in this study.

Keywords: Return On Asset, Return On Equity, Financial Distress

\section{A. PENDAHULUAN}

Indonesia pernah mengalami krisis ekonomi pada pertengahan 1997 sampai tahun 2005. Krisis di Indonesia sejak pertengahan tahun 1997 di mulai dengan menurunnya nilai rupiah yang sangat tajam, akibat meningkatnya permintaan dollar AS. Penyebab krisis ini tidak hanya karena struktur ekonomi yang lemah, tetapi karena utang swasta luar negeri yang telah mencapai jumlah yang cukup besar, akibatnya tingkat suku bunga dan inflasi meningkat tajam serta investasi berkurang sehingga kesehatan perusahaan banyak yang mengalami penurunan bahkan berpotensi untuk bangkrut.

Perbankan syariah sering disebut juga Bank Islam yaitu perbankan yang pelaksanaannya berdasarkan hukum Islam atau syariat. Karena berdasarkan hukum 
maka perbankan syariah tidak mengenal adanya bunga pinjaman, Karena bunga pinjaman dianggap riba dan berdosa. Dalam perbankan syariah yang dikenal adalah sistem bagi hasil atau nisbah yang prosesnya sama-sama diketahui dan disetujui oleh bank dan pihak nasabah.

Kondisi perekonomian di Indonesia yang masih belum menentu mengakibatkan tingginya risiko suatu perusahaan untuk mengalami kesulitan keuangan atau bahkan kebangkrutan. Kesalahan prediksi terhadap kelangsungan operasi suatu perusahaan di masa yang akan datang dapat berakibat fatal yaitu kehilangan pendapatan atau investasi yang telah ditanamkan pada suatu perusahaan. Oleh karena itu, pentingnya suatu model prediksi kebangkrutan suatu perusahaan menjadi hal yang sangat dibutuhkan oleh berbagai pihak seperti pemberi pinjaman, investor, pemerintah, akuntan, dan manajemen.

Analisis mengenai kebangkrutan suatu perusahaan sangat penting bagi berbagai pihak. Hal ini dikarenakan kebangkrutan suatu perusahaan tidak hanya merugikan pihak perusahaan saja, tetapi juga merugikan pihak lain yang berhubungan dengan perusahaan tersebut. Oleh karena itu, analisis prediksi kebangkrutan dapat dilakukan untuk memperoleh peringatan awal kebangkrutan (tanda-tanda awal kebangkrutan).

Semakin awal tanda-tanda kebangkrutan tersebut diketahui, maka akan semakin baik bagi pihak manajemen karena pihak manajemen bisa segera melakukan perbaikan- perbaikan agar perusahaan tidak mengalami kebangkrutan. Selain itu, bagi pihak eksternal perusahaan, prediksi kebangkrutan ini bisa digunakan sebagai dasar dalam pengambilan keputusan investasi. Apabila suatu bank dibiarkan dalam kondisi financial distress maka bank tersebut akan mengalami likuiditas dan kemungkinan bank tersebut akan ditutup.

Risiko kebangkrutan suatu perusahaan dapat dilihat dan diukur melalui laporan keuangan, dengan melakukan analisis terhadap rasio-rasio laporan keuangan perusahaan tersebut. Analisis rasio keuangan merupakan alat yang penting untuk mengetahui kondisi keuangan dan posisi keuangan perusahaan selama periode tertentu, dari hasil analisis tersebut akan diperoleh informasi yang dibutuhkan untuk mengetahui prediksi keuangan perusahaan di tahun berikutnya.

Kebangkrutan suatu bank dapat diatasi jika kinerja keuangan perusahaan membaik, kinerja keuangan perusahaan 
dapat dilihat dari perkembangan profitnya. Untuk mengetahui perkembangan profit dapat diukur dengan rasio profitabilitas. Ada beberapa pengukuran rasio profitabilitas yang digunakan yaitu Return On Assets (ROA) dan Return On Equity (ROE). (Hery, 2015 : 228).

Return On Asset adalah rasio keuangan perusahaan yang terkait dengan potensi keuntungan mengukur kekuatan perusahaan membuahkan keuntungan atau juga laba pada tingkat pendapatan, asset dan juga modal saham spesifik. Dalam mengukur identifikasi potensi financial distress ROA merupakan salah satu rasio utama dalam mengukur kinerja keuangan. Potensi financial distress suatu bank dapat dilihat dengan ROA apabila tingkat persentase ROA dari bank tersebut rendah sehingga berpotensi mengalami kebangkrutan. (Hery, 2015 : 47).

ROE adalah salah satu rasio keuangan yang sering digunakan oleh investor untuk menganalisa saham. Rasio ini menunjukkan tingkat efektivitas tim manajemen perusahaan dalam menghasilkan laba dari dana yang diinvestasikan pemegang saham. Dalam mengukur identifikasi financial distress ROE sangat berguna dalam mengukur kinerja karena ROE merupakan perbandingan antara laba bersih dengan modal sendiri. ROE digunakan untuk mengetahui tingkat laba setelah pajak dalam 12 bulan terakhir apabila dibandingkan dengan tingkat ekuitas yang dimilki oleh perusahaan. (Kasmir, 2012).

Berdasarkan berbagai latar belakang yang telah disebutkan diatas, peneliti tertarik untuk meneliti dan menganalisa potensi kebangkrutan bank karena kita sebagai investor membutuhkan financial distress untuk dapat mengetahui apakah suatu bank itu akan mengalami likuiditas atau tidak. Penelitian ini dikembangkan dengan judul "Pengaruh Rasio Profitabilitas Terhadap Financial Distress Pada Bank Umum Syariah Di Indonesia".

\section{B. METODE}

Penelitian ini dilakukan pada Bank Umum Syariah di Indonesia. Waktu penelitian dimulai dari bulan Juli 2019 sampai dengan bulan Februari 2020

1. Jenis Penelitian

Penelitian ini merupakan penelitian kuantitaif yaitu penelitian menggunakan data yang berbentuk angka atau data kualitatif yang diangkakan.(Rosady Ruslan,2008:27) Penelitian ini dilakukan dengan menggunakan metode regresi Data Panel. Data Panel (pool) yang merupakan gabungan antara data runtun waktu (time series) dengan data silang (cross section). Oleh karena itu, data panel memiliki 
gabungan karakteristik yaitu data yang terdiri atas beberapa obyek dan meliputi beberapa waktu. Umumnya pendugaan parameter dalam analisis regresi dengan data cross section dilakukan menggunakan pendugaan metode kuadrat kecil atau disebut Ordinary Least Square (OLS).(Sugiono,2012:43)

2. Teknik Pengumpulan Data

Adapun teknik pengumpulan data yang digunakan dalam penelitian ini adalah:

a. Teknik Kepustakaan, yaitu dengan membaca literatur buku yang ada kaitannya dengan tema dan judul penelitian. Teknik kepustakaan dari penelitian ini diambil dari buku-buku dan laporan-laporan yang ada di laporan keuangan objek yang diteliti.

Teknik dokumentasi, dalam proses pengumpulan data peneliti menggunakan dokumentasi dengan mengakses laporan keuangan Bank Umum Syariah publikasi tahunan melalui website resmi masing-masing bank umum syariah di indonesia.

\section{HASIL DAN PEMBAHASAN}

\section{Statistik deskriptif}

Berdasarkan statistik variabel penelitian maka dapat diinterpretasikan bahwa:

a. Financial Distress memiliki nilai minimum sebesar -4,300000 pada bank umum syariah dan nilai maksimum sebesar 0,600000. secara keseluruhan diperoleh rata-rata sebesar -3,208333 dan standar deviasi variabel sebesar 0,919154.

b. Return On Asset memiliki nilai minimum sebesar 0,020000persen pada bank umum syariah dan nilai maksimum sebesar 20,13000 persen. Secara keseluruhan diperoleh rata-rata sebesar 2,352333 persen dan standar deviasi variabel sebesar 3,568321 persen.

c. Return On Equity memiliki nilai minimum sebesar 0,200000 persen pada bank umum syariah dan nilai maksimum sebesar 36,50000 persen. Secara keseluruhan diperoleh rata-rata sebesar 9,500833 persen dan standar deviasi variabelsebesar 9,355596 persen.

2. Hasil Pengolahan

1. Pemilihan Model Data Panel

a. Common Effect

Model ini merupakan model paling sederhana dibandingkan dengan kedua model lainnya. Model ini tidak dapat membedakan variab antara silang tempat dan titik waktu karena memiliki intersep yang tetap, dan bukan bervariasi secara random.

b. Fixed Effect

Pada asumsi ini, variabel terletak pada individu yang factor waktunya diabaikan sehingga model regresi yang digunakan adalah model regresi dummy untuk mengungkap adanya perbedaan intersep.

c. Random Effect 
Perbedaan model fixed effect dari model dummy untuk data panel menimbulkan permasalahan hilangnya derjat bebas dari model. Selain itu, model dummy bisa menghalangi kita untuk mengetahui model lainnya.

2. Penentuan Model Data Panel

a. Uji Chow

Penentuan model terbaik anatara common effect dan fixed effect digunakan uji chow. Hipotesis dalam uji chow adalah dengan membandingkan perhitungan nilai chi-square hitung dengan chisquare tabel. Hasil uji chow

disajikan pada tabel berikut:

Tabel 1 Hasil Uji Chow lebih kecil dai sig 0,05 sehingga model yang terpilih adalah fixed effect.

b. Uji Hausman

Penentuan model terbaik antara fixed effect dan random effect digunakan uji hausman. Statistik dalam uji hausman mengikuti distribusi statistik chi-square dengan degree of freedom. Jika nilai statistik hausman lebih besar dari nilai kritisnya, maka HO ditolak dan model yang lebih tepat adalah model fixed effect sedangkan sebaliknya bila nilai statistik hausman lebih kecil dai nilai kritisnya, maka model yang tepat adalah random effect. Hasil uji hausman disajikan pada tabel berikut:

Tabel 2 Hasil Uji Hausman

\begin{tabular}{|c|c|c|}
\hline \multicolumn{3}{|c|}{ Redundant Fixed Effects Tests } \\
\hline Pool: YENNITA & & \\
\hline \multicolumn{3}{|c|}{ Test cross-section fixed effects } \\
\hline Effects Test & Statistic & d.f. \\
\hline Cross-section $\mathrm{F}$ & 5.359888 & $(11,46)$ \\
\hline $\begin{array}{c}\text { Cross-section Chi- } \\
\text { square }\end{array}$ & 49.495573 & 11 \\
\hline
\end{tabular}

Sumber: Hasil Pengolahan Output Eviews 9.

Berdasarkan hasil uji chow pada tabel IV.8, untuk melihat model mana yang harus dipilih antara model common effect dengan model fixed effect maka ditentukan dari nilai probability dari cross section $\mathrm{F}$ lebih kecil dari pada 0,05 maka model yang terpilih adalah fixed effect. Dan tabel diatas menunukkan nilai probability coss section $F$ nya adalah 0,0012
Berdasarkan tabel IV.9 dapat dilihat jika nilai X2 stat sebesar 6,972754 sedangkan nilai X2 tabel dengan d.f 2 sebesar 5,991. Maka dapat disimpulkan bahwa nilai X2 stat > nilai X2 tabel, maka model yang lebih tepat dalam penelitian ini yaitu fixed effect. 
Berdasarkan hasil kedua uji diatas dapat disimpulkan bahwa model yang akan digunakan adalah fixed effect. Uji lagrang multiplier dalampenelitian ini ditiadakan, karena hasil dari kedua uji sebelumnya menunjukkan hasil yang sama.

3. Uji Normalitas

Uji normalitas digunakan untuk mengetahui apakah data berdistribusi normal atau tidak.

\section{Tabel 3}

\section{Hasil Uji Normalitas}

\begin{tabular}{|c|c|c|c|c|c|c|c|c|c|}
\hline No & Variabel & Probability & Hasil & Kesimpulan & & & & 0,05 & Berdis \\
\hline \multirow[t]{2}{*}{1.} & \multirow[t]{2}{*}{ FD_BMI } & \multirow[t]{2}{*}{0,657336} & $>$ & Data & & & & & Normal \\
\hline & & & 0,05 & $\begin{array}{c}\text { Berdistribusi } \\
\text { Normal }\end{array}$ & \multirow[t]{2}{*}{18.} & \multirow[t]{2}{*}{ ROA_BSM } & \multirow[t]{2}{*}{0,777874} & \multirow[t]{2}{*}{$\begin{array}{c}> \\
0,05\end{array}$} & $\begin{array}{c}\text { Data } \\
\text { Berdistribusi }\end{array}$ \\
\hline \multirow[t]{2}{*}{2.} & \multirow[t]{2}{*}{ FD_BRIS } & \multirow[t]{2}{*}{0,680344} & $>$ & Data & & & & & Normal \\
\hline & & & 0,05 & $\begin{array}{c}\text { Berdistribusi } \\
\text { Normal }\end{array}$ & \multirow[t]{2}{*}{19.} & \multirow[t]{2}{*}{$\begin{array}{l}\text { ROA_MEG } \\
\text { AS }\end{array}$} & \multirow[t]{2}{*}{0,762684} & \multirow[t]{2}{*}{$\begin{array}{c}> \\
0,05\end{array}$} & $\begin{array}{l}\text { Data } \\
\text { Berdistribusi }\end{array}$ \\
\hline \multirow[t]{2}{*}{3.} & \multirow[t]{2}{*}{ FD_BNIS } & \multirow[t]{2}{*}{0,866991} & $>$ & Data & & & & & Normal \\
\hline & & & 0,05 & $\begin{array}{c}\text { Berdistribusi } \\
\text { Normal }\end{array}$ & \multirow[t]{2}{*}{20.} & \multirow[t]{2}{*}{ ROA_BKPS } & \multirow[t]{2}{*}{0,736358} & \multirow[t]{2}{*}{$\stackrel{>}{0,05}$} & $\begin{array}{c}\text { Data } \\
\text { Berdistribusi }\end{array}$ \\
\hline \multirow[t]{2}{*}{4.} & \multirow{2}{*}{$\begin{array}{l}\text { FD_PANIN } \\
\text { S }\end{array}$} & \multirow[t]{2}{*}{0,865592} & $>$ & Data & & & & & Normal \\
\hline & & & 0,05 & $\begin{array}{c}\text { Berdistribusi } \\
\text { Normal }\end{array}$ & \multirow[t]{2}{*}{21.} & \multirow[t]{2}{*}{ ROA_VICS } & \multirow[t]{2}{*}{0,674035} & \multirow[t]{2}{*}{$\begin{array}{c}> \\
0,05\end{array}$} & $\begin{array}{c}\text { Data } \\
\text { Berdistribusi }\end{array}$ \\
\hline \multirow[t]{2}{*}{5.} & \multirow[t]{2}{*}{ FD_BCAS } & \multirow[t]{2}{*}{0,838583} & $>$ & Data & & & & & Normal \\
\hline & & & 0,05 & $\begin{array}{c}\text { Berdistribusi } \\
\text { Normal }\end{array}$ & \multirow[t]{2}{*}{22.} & \multirow[t]{2}{*}{$\begin{array}{l}\text { ROA_MAY } \\
\text { BS }\end{array}$} & \multirow[t]{2}{*}{0,710621} & \multirow[t]{2}{*}{$\stackrel{>}{0,05}$} & $\begin{array}{l}\text { Data } \\
\text { Berdistribusi }\end{array}$ \\
\hline 6. & FD_BSM & 0,416295 & $>$ & Data & & & & & Normal \\
\hline & & & 0,05 & $\begin{array}{c}\text { Berdistribusi } \\
\text { Normal }\end{array}$ & 23. & $\begin{array}{l}\text { ROA_ACE } \\
\text { HS }\end{array}$ & 0,708245 & $\stackrel{>}{>05}$ & $\begin{array}{l}\text { Data } \\
\text { Berdistribusi }\end{array}$ \\
\hline 7. & FD_MEGA & 0,809128 & $>$ & Data & & & & & Normal \\
\hline & & & 0,05 & $\begin{array}{c}\text { Berdistribusi } \\
\text { Normal }\end{array}$ & 24. & $\begin{array}{l}\text { ROA_BTPN } \\
S\end{array}$ & 0,749734 & $\stackrel{>}{>, 05}$ & $\begin{array}{l}\text { Data } \\
\text { Berdistribusi }\end{array}$ \\
\hline 8. & FD_BKPS & 0,770355 & $>$ & Data & & & & & Normal \\
\hline & & & 0,05 & $\begin{array}{c}\text { Berdistribusi } \\
\text { Normal }\end{array}$ & 25. & ROE_BMI & 0,745351 & $\stackrel{>}{0,05}$ & $\begin{array}{c}\text { Data } \\
\text { Berdistribusi }\end{array}$ \\
\hline 9. & FD_VICS & 0,740131 & $>$ & Data & & & & & Normal \\
\hline & & & 0,05 & $\begin{array}{c}\text { Berdistribusi } \\
\text { Normal }\end{array}$ & 26. & ROE_BRIS & 0,816526 & $\stackrel{>}{0,05}$ & $\begin{array}{l}\text { Data } \\
\text { Berdistribusi }\end{array}$ \\
\hline
\end{tabular}


Yennita Sari ${ }^{1}$, Nofinawati ${ }^{2}$, Sarmiana Batubara ${ }^{3}$, Ferri Alfadri ${ }^{4}$

POINT Vol. 1, No. 1, Jul 2020

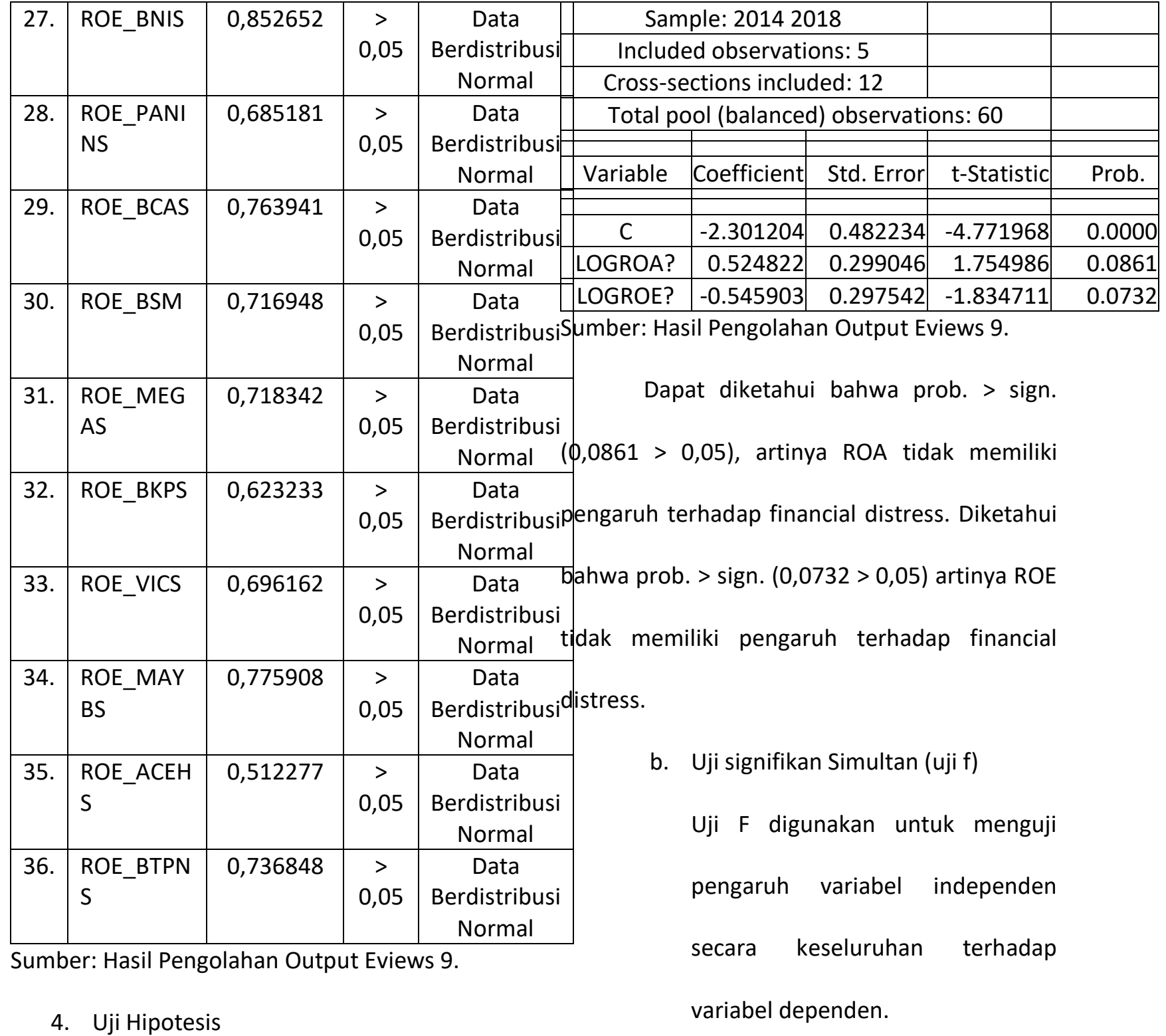

a. Uji signifikan Parsial (uji t)

Uji statistik $\mathrm{t}$ digunakan untuk menguji pengaruh masing-masing variabel independen yang digunakan terhadap variabel dependen dengan menganggap variabel lain bernilai konstan.

Tabel 4 Hasil Uji t

\begin{tabular}{|c|c|}
\hline Dependent Variable: FD? & 3. \\
\hline Method: Pooled Least Squares & \\
\hline Date: $02 / 11 / 20$ Time: 01:44 & \\
\hline
\end{tabular}

a. Return On Asset terhadap financial distress

Tabel 5

Hasil uji F

\begin{tabular}{|c|c|c|c|}
\hline Fstatistik & $\begin{array}{c}\text { Prob. } \\
\text { Fstat }\end{array}$ & $\begin{array}{c}\text { Ftabel } \\
\alpha 5 \%\end{array}$ & kesimpulan \\
\hline 4,664855 & 0,000038 & 2,77 & Berpengaruh \\
\hline
\end{tabular}

Sumber:Hasil Pengolahan Output Eviews 9.

Dapat diketahui bahwa Fhitung > Ftabel $(4,664855>2,77)$ yang berarti Ha diterima, artinya bahwa variabel ROA dan ROE secara simultan mempengaruhi financial distress.

asil Pembahasan 
Hery menyatakan bahwa Return On Asset berpengaruh terhadap financial distress yaitu jika persentase nilai Return On Asset berada pada nilai tinggi maka dapat dikatakan bahwa perusahaan atau bank masih jauh dari kondisi financial distress. Dari hasil uji t diketahui bahwa variabel Return On Asset tidak berpengaruh secara signifikan terhadap financial distress dimana hasil tersebut didukung oleh penelitian Alfinda Rohmadini dengan hasil yang sama yaitu Return On Asset tidak berpengaruh terhadap financial distress.Dan penelitian ini tidak sejalan dengan penelitian Sri Riski Mutiah dimana Return On Asset berpengaruh terhadap financial distress.

b. Return On Equity terhadap financial distress

Hery menyatakan bahwa Return On Equity berpengaruh terhadap financial distress yaitu jika persentase nilai Return On Equity berada pada nilai tinggi maka dapat dikatakan bahwa perusahaan atau bank masih jauh dari kondisi financial distress. Dari hasil uji t diketahui bahwa variabel Return On Equity tidak berpengaruh secara signifikan terhadap financial distress dimana hasil tersebut didukung oleh penelitian Alfinda Rohmadini dengan hasil yang sama yaitu Return On
Equity tidak berpengaruh terhadap financial distress. Dan penelitian ini tidak sejalan dengan penelitian Sri Riski Mutiah dimana Return On Equity berpengaruh terhadap financial disstress.

c. Return On Asset dan Return On Equity terhadap financial distress

Hasil uji keseluruhan variabel Return On Asset dan Return On Equity secara bersamaan berpengaruh signifikan terhadap financial distress tahun 2014-2018. Didukung oleh penelitian Alfinda Rohmadini menyatakan bahwa ROA dan ROE secara bersamaan berpengaruh signifikan terhadap financial distress.

\section{PENUTUP}

\section{Kesimpulan}

Berdasarkan hasil pengolahan data dari penelitian ini yang berjudul "Pengaruh Rasio Profitabilitas Terhadap Financial Distress Pada Bank Umum Syariah Tahun 2014-2018" di dapatkan kesimpulan sebagai berikut:

1. Return On Asset tidak berpengaruh signifikan terhadap financial distress pada Bank Umum Syariah tahun 20142018.

2. Return On Equity tidak berpengaruh signifikan terhadap financial distress pada Bank Umum Syariah tahun 20142018. 
POINT Vol. 1, No. 1, Jul 2020

3. Return On Asset dan Return On Equity berpengaruh signifikan terhadap financial distress pada Bank Umum Syariah tahun 2014-2018.

\section{Saran}

Penelitian ini merekomendasikan bagi peneliti selanjutnya agar bisa dikembangkan kedepannya dan tidak hanya focus pada variabel dana pihak ketiga karena masih banyak variabellain yang dapat mempengaruhi pembiayaan.

\section{DAFTAR PUSTAKA}

Dwi Suwikyo, Kamus Lengkap Ekonomi Islam, Yogyakarta: Total Media.

Hery, Analisis Laporan Keuangan, Yogyakarta: Center for Academic Publishing Service, 2015.

Husein Umar, Metode Penelitian Untuk Skripsi dan Tesis Bisnis, Jakarta: Rajawali Pers, 2013
Husein Ummar, Metode Riset Bisnis, Jakarta:

PT. Gramedia Pustaka Utama, 2003.

Kasmir, Analisis Laporan Keuangan, Jakarta: PT. Grafindo Persada.

Munawir, Analisis Laporan Keuangan, Yogyakarta: Liberty, 2007.

Rosady Ruslan, Metodologi Penelitian Public Relations dan Komunikasi, Jakarta: PT RajaGrafindo Persada, 2008.

Sochrul R. Ajija, Cara Cepat Menguasai Eviews, Jakarta: Salemba Empat, 2011.

Sudana, I, M, Manajemen Keuangan Perusahaan, Teori dan Praktek, Jakarta: Erlangga, 2011.

Sugiono, Metode Penelitian Bisnis (Pendekatan Kuantitatif, Kualitatif, dan R\&D), Bandung: CV Alfabeta, 2012.

Zaki Baridwan, Intermedite Accounting, Yogyakarta: BPFE-yogyakarta, 2012. 